\title{
Allelic diversity of butyrophilin (BTN1A1) gene in Indian bovines
}

\author{
Manoj Kumar ${ }^{1,2}$, Poonam Ratwan ${ }^{2}$, Ramendra Das ${ }^{1,2}$, Alka Chopra ${ }^{2}$, and Vikas Vohra ${ }^{1, *}$ \\ ${ }^{1}$ ICAR-National Bureau of Animal Genetic Resources, GT Road Bypass, Karnal 132001 (Haryana), India \\ ${ }^{2}$ ICAR-National Dairy Research Institute, GT Road, Karnal 132001 (Haryana), India \\ *Corresponding author: vohravikas@gmail.com
}

\begin{abstract}
Indian milch bovines comprise $58.56 \%$ of the total livestock population ( 512.05 million) in the country and primarily include native and crossbred cattle (37.28\%) and water buffaloes (21.28\%). Milk and milk products are essential food items in Indians' diet, especially in children and the elderly and senile. Milk fat is an important constituent of milk and has an economic value and its percentage in milk varies between species and breeds within species. Butyrophilin (BTN1A1) is a membrane protein that regulates the secretion of lipids and size of a fat globule in milk. The present study was conducted on 538 bovines from 11 breeds/populations adapted to different parts of India, with an aim to screen and determine the major allele of the BTN1A1 gene. The genotyping of samples was done using PCR-RFLP based tests. The results indicated that exon8 of the BTN1A1 gene was polymorphic in the Tharparkar, Sahiwal, Jhari, and Belahi populations of the native cattle, as well as the Holstein Friesian and Jersey crossbreeds. Meanwhile, exon 8 was monomorphic in the Murrah, Chilika, Gojri, Chhattisgarhi, and Bargur populations of water buffalo. Allele $\mathbf{A}$ was identified as the major allele in Indian bovines. We conclude that variations in the BTN1A1 gene can serve as an excellent genetic marker in the selection of cattle with higher milk fat, and can be applied when formulating their breeding plans.
\end{abstract}

KEYWORDS butyrophilin; fat; milk; polymorphism; SNP

\section{Introduction}

Indian dairy industry is focused on invention of efficient and economical ways of increasing milk production. Selection of superior milch bovines without increasing the size of dairy herd and further their mating to raise improved progenies is one of the ways to enhance the milk production. Of late, there has been an emphasis to select genetically superior milch bovines based on polymorphic candidate genes and DNA markers rather than conventional phenotypic selection. Number of SNPs has shown positive and significant associations with milk fat secretion among different exotic breeds of cattle but they have not been explored fully among Indian bovines. In India, current selection and breeding strategies focus only to increase milk yield in milch animals. There is need to put efforts to select milch bovines based on milk composition and its quality like fat yield owing to dependency of dairy economics to a large extent on fat yield. Moreover, in organized sector and dairy co-operatives, producers are paid on the basis of fat corrected milk (FCM). Marker based selection followed with suitable breeding methods for high milk fat yield without affecting milk production can help in genetic selection among milch bovines. Selection for milk and milk constituent (fat) traits can be im- proved by utilizing information from SNPs linked to QTL. It is important to explore genetic variations at DNA level in dairy animals and subsequently their use in formulating breeding programmes. Several studies in exotic cattle have revealed large genetic variations in bovine milk fat and milk fat composition (Soyeurt et al. 2007; Stoop et al. 2008). A number of SNPs in candidate genes having role in fat synthesis are found to be associated with milk fat percentage or milk fat yield. Various candidate genes have been identified for fat synthesis such as Fatty acid synthase (FASN) (Vohra et al. 2015; Kumar et al. 2016b, 2017), Diacylglycerol-acyl-transferase 1 (DGAT1) (Grisart et al. 2002) and Signal transducer and activator of transcription 1 (STAT1) gene (Cobanoglu et al. 2006; Kumar et al. 2015, 2016a). The main aim of genetic research in farm animals is identification of genes influencing economically important traits that could be useful in breeding programme (Asadollahpour Nanaei et al. 2013).

Butyrophilin (BTN1A1) is a candidate gene important to milk yield and composition (fat). This protein is directly involved in the secretion of fat globules at the apical surface of mammary epithelial cells throughout lactation (Jack and Mather 1990). DNA level variations may help to identify possible hybridization as well as past evolutionary events and contributes to the genetic characterization 
of a livestock population. A protein's expression may be altered by a change in amino acids due to exonic region variations in a gene (Geldermann 1975). A group of membranous proteins helps fat droplets in getting proper shape during secretion and BTN1A1 plays a significant role during the process of lactogenesis (Bhattacharya et al. 2007). BTN1A1 is the most abundant protein in milk fat globule membrane and is particularly expressed in lactating mammary tissue. BTN1A1 is produced at the end of pregnancy and is maintained throughout lactation (Ogg et al. 2004). Among the total protein associated with fat globule membrane of bovine milk, BTN1A1 constitutes more than $40 \%$ by weight (Mather and Jack 1993). This protein is usually sandwiched between plasma membrane and surface of fat droplets (Wooding and Kemp 1975), and its characteristic feature is non-solubility in non-ionic detergent due to its hydrophobic property (Freudenstein et al. 1979). During budding and secretion of fat droplets into milk, BTN1A1 is incorporated into the milk-fat-globule membrane. The budding of droplets at cell surface is initiated by interactions between cytoplasmic tail of BTN and other proteins like xanthine oxidase, fatty acid synthetase, GTP-binding proteins and lipids, though, butyrophilin may function as an imperative receptor for cytoplasmic fat droplets (Jack and Mather 1990). The structural relationship of butyrophilin to proteins of the immune system is suggestive of its possible immunologic function, distinctive to milkfat secretion (Taylor et al. 1996a). A number of mammalian species including humans (Taylor et al. 1996b), cattle (Jack and Mather 1990) and mice (Ishii et al. 1995) possess the BTN1A1 gene. Bovine butyrophilin gene consists of 8 exons and 7 introns and is located on the $23^{\text {rd }}$ chromosome (Ashwell et al. 1996). BTN1A1 is possibly QTL candidate gene affecting milk yield and composition in dairy animals (Komisarek and Dorynek 2003). Franke et al. (1981) suggested that butyrophilin is widely expressed during lactation and is specific to mammary tissue.

Genetic variations can be analyzed at both the phenotypic and genetic levels and are key factors for the improvement of the performance of animals. It is wellknown that every trait is controlled by gene(s) and nowadays it is of utmost importance to identify gene(s) in order to explore genotype-trait relationships. As such, identification of SNPs subsisting in the genome is required to detect the effect of genotypes on economically important traits. SNPs help to know the evolutionary relationships between species along with searching molecular markers. Keeping all this in view, the present study was undertaken to screen variations in the BTN1A1 gene of different indigenous, crossbred cattle and riverine buffaloes of India.

\section{Materials and methods}

\subsection{Population studied and sample size}

The studied bovine populations, namely Murrah (North India), Sahiwal and Tharparker (Northwestern India) and crossbreeds of Holstein Friesian (North India), and Jersey cattle (coastal parts of India) are primary milch breeds and have larger spread across India, contributing significantly to the national milk production. Populations like Belahi and Gojri (North India), Chhattisgarhi and Jhari (Central India), Chilika (Eastern India), and Bargur (South India) besides milk production are also used for draught power and have better adaptability, extensively managed and limited distribution but strong socio-economic utility to their keepers. Random blood samples (approximately 8 to $10 \mathrm{~mL}$ ) were aseptically collected from the jugular veins of 538 genetically unrelated bovines, specifically Murrah buffalo $(n=200)$, Gojri buffalo $(n=40)$, Chhattisgarhi buffalo $(\mathrm{n}=40)$, Chilika buffalo $(\mathrm{n}=30)$, Bargur buffalo $(n=30)$, Tharparkar cow $(n=30)$, Sahiwal cow $(n=$ $30)$, Belahi cow $(n=48)$, Jhari cow $(n=30)$, Holstein Fries crossbreed cattle (Karan Fries) $(\mathrm{n}=30)$, and Jersey crossbreed cow $(n=30)$. Samples of Tharparkar, Sahiwal, Karan Fries cattle, and Murrah buffaloes were collected from organized herd of ICAR-National Dairy Research Institute, Karnal (Haryana) and blood samples of Gojri, Chhattisgarhi, Chilika, Bargur, Belahi, Jhari, and Jersey crossbreed were collected from their respective breeding tract in India.

\subsection{DNA isolation and primers used}

Genomic DNA was isolated from aseptically collected venous blood using standard phenol/chloroform method with minor modifications (Sambrook and Russell 2001). Quality check and quantification were done by nanodrop spectrophotometer and electrophoresis on $0.8 \%$ agarose gel. DNA concentration was determined and samples were diluted 10-40 times (approx. 50-80 ng/ $\mu \mathrm{L}$ ) with MiliQ water. A 501 bp butyrophilin gene fragment covering part of exon 8 was amplified with a pair of primers, 5'- TGGAGCTCTATGGAAATGGG-3' (forward) and 5'TACCCAACAGGAAGAAACAG-3' (reverse) with $\mathrm{T}_{\mathrm{M}}$ of $60.4^{\circ} \mathrm{C}$ and $59.5^{\circ} \mathrm{C}$, respectively (Taylor et al. 1996a).

\subsection{PCR amplification and genotyping conditions}

DNA amplification of exon 8 region of BTN1A1 gene was done by thermocycler. The optimization of PCR was done to get the best possible amplification of product. PCR was carried out in $25 \mu \mathrm{L}$ reaction volumes consisting of 200 $\mu \mathrm{M}$ of each dNTP, $5 \mathrm{pM}$ of each primer, $1.5 \mathrm{mM} \mathrm{MgCl}_{2}$ and 1.0 U Taq polymerase (Invitrogen, CA). Amplification was standardised in lab using MASTERCYCLER EP (Eppendorf, Germany) with an initial denaturation at $95^{\circ} \mathrm{C}$ for 4 min followed by 30 cycles of $94^{\circ} \mathrm{C}$ for $60 \mathrm{~s}$, annealing temperature $58^{\circ} \mathrm{C}$ for $60 \mathrm{~s}$ and $72^{\circ} \mathrm{C}$ for $60 \mathrm{~s}$, with a final extension at $72^{\circ} \mathrm{C}$ for $10 \mathrm{~min}$. All samples were screened for BTN1A1 gene polymorphism using PCR-RFLP test using HaeIII restriction enzyme at $37^{\circ} \mathrm{C}$ for 6 to $8 \mathrm{~h}$ and genotyping was done. Genotypes were evaluated by running a small aliquot of PCR-RFLP product on 3\% agarose gel. 


\subsection{Statistical analysis}

Gene counting method (Falconer and Mackay 1996) was used for calculating genotype and allele frequencies of exon 8 of BTN1A1 gene. A chi-square test was also performed to check Hardy-Weinberg equilibrium status in the studied population. All the analysis was carried out using the SPSS (SPSS Inc. 2001).

\section{Results and discussion}

Genomic DNA isolated from whole blood was of good in quality and concentration. Standardization of the optimum PCR reaction conditions was achieved in the lab and the PCR product of 501 bp was amplified satisfactorily, with repetitions of results at the same amplification conditions among all of the samples of 11 bovine populations studied across India.

Digestion of PCR amplified product by HaeIII restriction enzyme revealed three distinct restriction patterns. The first pattern (genotype AA) showed two bands of 316 and 162 bp while the second pattern (genotype BB) showed 283 and $162 \mathrm{bp}$. The third pattern, a heterozygote (genotype AB) depicted three bands of 316, 283 and 162 bp in agarose gel (Figure 1, 2). Smaller fragments of 23 bp, $56 \mathrm{bp}$ and $33 \mathrm{bp}$ could not be resolved in the gel due to limitations of agarose gel electrophoresis used to revolve the DNA. Thus, this locus revealed the presence of two alleles, namely $\mathrm{A}$ and $\mathrm{B}$, in the indigenous and crossbred cattle. Conversely, in the case of the different breeds in the buffalo population allele A was fixed and only band patterns 316 and 162 bp were present and all 340 samples showed the AA genotype (Figure 3).

Among the native Belahi and Jhari cattle, the BTN1A1 gene was sufficiently polymorphic and showed three expected genotypes, although the BB genotype was found to be less frequent (Table 1). In Tharparkar and Sahiwal cattle, the BB genotype was absent, probably because these populations were sampled from an organized herd where selection is practiced, whereas the Belahi and Jhari cattle could reveal a higher degree of genetic variation as sampling in these cattle was carried out from field

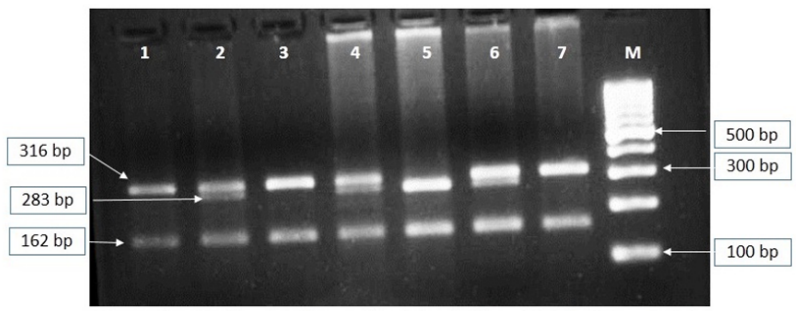

FIGURE 1 Polymorphic Haell digestion pattern of PCR product (501 bp) in exon 8 of BTN1A1 gene region in Jersey crossbreed (Lanes 1, 2), Karan Fries (Lane 3, 4), and Jhari (Lane 5, 6, 7) cattle. Lane 1, 3, 7 = AA genotype (product band size $316 \mathrm{bp}$ and $162 \mathrm{bp}$ ); Lane 2, 4, 6 = AB genotype (product band size 316 bp, $283 \mathrm{bp}$, and $162 \mathrm{bp}$ ); Lane 5 = BB genotype (product band size $283 \mathrm{bp}$ and 162 bp); Lane $\mathrm{M}=100$ bp ladder. herds/breeding tract. Karan Fries cattle, having exotic blood from the Holstein breed, showed all three of the expected genotypes (Table 1), but the BB genotype was rare. In the Jersey crossbreed, the BB genotype was entirely absent. Irrespective of the nature of the sampling of the water buffaloes, all of the five studied populations were monomorphic and had a single genotype (AA).

Allele frequencies for $\mathrm{A}$ and $\mathrm{B}$ allele were found to be 0.85 and 0.15 in Tharparkar, 0.82, and 0.18 in Sahiwal, 0.84 and 0.16 in Jhari, 0.86 and 0.14 in Belahi, 0.82 and 0.18 in Karan Fries cattle, and 0.83 and 0.17 in Jersey crossbreeds indicating that $\mathrm{A}$ is a predominant allele for exon 8 of BTN1A1 gene among Indian bovines. These were in correspondence with earlier reported frequencies of BTN1A1 allele as 0.875 and 0.125 (Taylor et al. 1996a), 0.85 and 0.15 (Husaini et al. 1999), 0.84 and 0.14 (Sadr et al. 2008), 0.88 and 0.12 (Komisarek and Dorynek 2003), 0.87 and 0.13 (Bhattacharya et al. 2004), 0.69 and 0.31 (Muszyńska et al. 2010) in different milch bovines. Highest frequency was observed for AA genotype and A allele whereas lowest frequency was found for BB genotype and B allele. Several researchers (Husaini et al. 1999; Zegeye et al. 1999; Badola et al. 2004; Mao et al. 2004) had reported similar results. Milk fat percentage in Indian buffalo breeds averages around $8 \%$ whereas it is around $5 \%$ in native cattle and in exotic crossbreeds it is around 4\% (Vohra and Chakravarty 2011). Thus, this variation

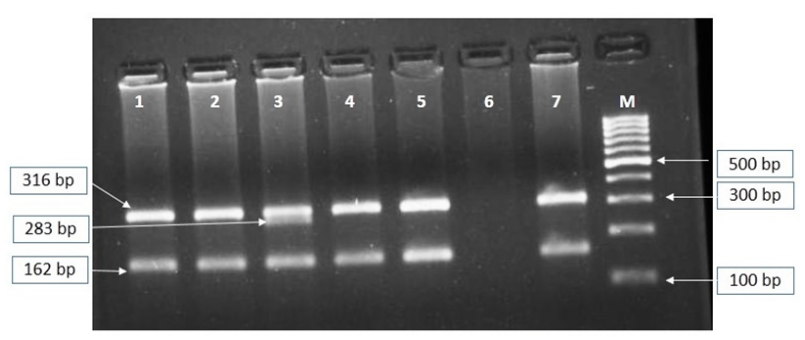

FIGURE 2 Polymorphic Haell digestion pattern of PCR product (501 bp) in exon 8 of BTN1A1 gene region in Sahiwal (Lanes 1, 3), and Tharparkar (Lane 4, 5, 6) cattle. Lane 1, 2, 4, 5, 6 = AA genotype (product band size $316 \mathrm{bp}$ and $162 \mathrm{bp}$ ); Lane $3=\mathrm{AB}$ genotype (product band size 316 bp, 283 bp, and 162 bp); Lane $M=100$ bp ladder.

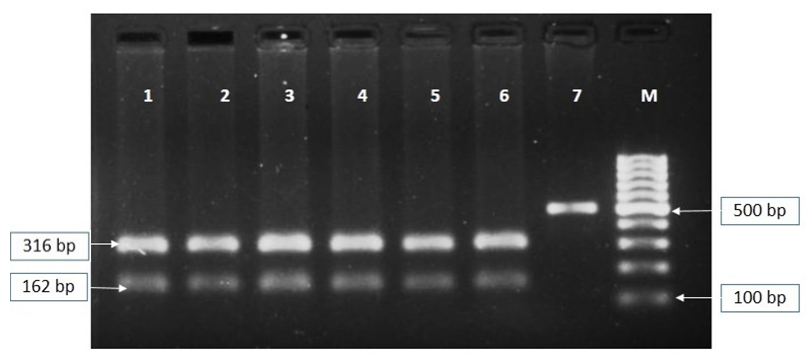

FIGURE 3 Monomorphic Haelll digestion pattern of PCR product (501 bp) in exon 8 of BTN1A1 gene region in Murrah (Lanes 1, 2), Gojri (Lane 3, 4), and Chhattisgarhi (Lane 5, 6) buffaloes. Lane 1 to 6 = AA genotype (product band size $316 \mathrm{bp}$ and $162 \mathrm{bp}$ ); Lane $7=$ uncut PCR product as control (501 bp); Lane $\mathrm{M}=100$ bp ladder. 
TABLE 1 Genotype and allele frequencies of BTN1A1 gene in Indian milch bovines.

\begin{tabular}{|c|c|c|c|c|c|c|c|}
\hline \multirow[t]{2}{*}{ Name of population } & \multirow[t]{2}{*}{ Distribution (state) } & \multirow[t]{2}{*}{ Sample size } & \multicolumn{3}{|c|}{ Genotype frequency } & \multicolumn{2}{|c|}{ Allele frequency } \\
\hline & & & $\mathrm{AA}$ & $A B$ & $\mathrm{BB}$ & $A$ & B \\
\hline \multicolumn{8}{|l|}{ Indigenous cattle } \\
\hline Tharparkar & Rajasthan & 30 & 0.70 & 0.30 & 0.00 & 0.85 & 0.15 \\
\hline Sahiwal & Rajasthan, Punjab & 30 & 0.63 & 0.37 & 0.00 & 0.82 & 0.18 \\
\hline Jhari & Telangana & 30 & 0.70 & 0.27 & 0.03 & 0.84 & 0.16 \\
\hline Belahi & Haryana, Chandigarh & 48 & 0.76 & 0.20 & 0.04 & 0.86 & 0.14 \\
\hline Total & & 138 & 0.69 & 0.29 & 0.02 & 0.84 & 0.16 \\
\hline \multicolumn{8}{|l|}{ Crossbred cattle } \\
\hline Karan Fries & Haryana, Punjab & 30 & 0.67 & 0.30 & 0.03 & 0.82 & 0.18 \\
\hline Jersey crossbreed & Himachal Pradesh, coastal parts & 30 & 0.65 & 0.35 & 0.00 & 0.83 & 0.17 \\
\hline Total & & 60 & 0.66 & 0.33 & 0.01 & 0.83 & 0.17 \\
\hline \multicolumn{8}{|l|}{ Water buffalo } \\
\hline Murrah & Haryana & 200 & 1.00 & 0.00 & 0.00 & 1.00 & 0.00 \\
\hline Gojri & Punjab, Himachal Pradesh & 40 & 1.00 & 0.00 & 0.00 & 1.00 & 0.00 \\
\hline Chhattisgarhi & North \& Central Chhattisgarh & 40 & 1.00 & 0.00 & 0.00 & 1.00 & 0.00 \\
\hline Chilika & Odisha & 30 & 1.00 & 0.00 & 0.00 & 1.00 & 0.00 \\
\hline Bargur & Tamil Nadu & 30 & 1.00 & 0.00 & 0.00 & 1.00 & 0.00 \\
\hline Total & & 340 & 1.00 & 0.00 & 0.00 & 1.00 & 0.00 \\
\hline
\end{tabular}

in BTN1A1 gene i.e. A allele could be one of the allelic marker associated with high milk fat in Indian bovines.

Chi square $\left(x^{2}\right)$ test was used to evaluate HardyWeinberg equilibrium (HWE) in the studied populations. Populations followed Hardy-Weinberg equilibrium in indigenous and crossbred cattle with $\chi^{2}$ values $0.879,1.39$, 0.103, 0.124, 0.819, and 0.007 in Tharparkar, Sahiwal, Jhari, Belahi, Jersey crossbreed, and Karan Fries cattle, respectively. Overall $x^{2}$ value of different breeds of indigenous and crossbreed cattle was 2.321. The calculated chisquare values were found to be less than tabulated values at $1 \%$ (9.21) and 5\% (5.99), indicating non-significant values implying that HWE was maintained in the populations. Thus it can be inferred that so far the studied population of indigenous and crossbred cattle followed random mating and has not been subjected to selection with respect to BTN1A1 gene in Indian bovines.

\section{Conclusions}

BTN1A1 is possibly a candidate gene affecting fat percent, an economically important trait, in dairy bovines. It may be inferred from our findings that BTN1A1 gene is variable in cattle and can be successfully be detected through PCRRFLP based test. Indian water buffalo seems to have been fixed for $\mathbf{A}$ allele as the locus is monomorphic across the breeds of buffalo in India. Further it is hypothesised that early selection based on A allele of exon 8 of BTN1A1 gene could serve as one of the essential SNP for genomic chip/genetic marker based selection strategy if adopted for Indian cattle.

\section{Acknowledgments}

Authors thank Director, ICAR-National Bureau of Animal Genetic Reseources-Karnal (Haryana) and Director, ICAR-National Dairy Research Institute for providing the necessary facilities and financial support.

\section{Authors' contributions}

VV designed the study. MK, PR, RD carried out the laboratory work. AC analyzed the data. MK and VV wrote the manuscript. All authors read and approved the final version of manuscript.

\section{Competing interests}

There are no competing interests.

\section{References}

Asadollahpour Nanaei H, Ansari Mahyari S, Edriss MA, Rostami M, Pirzad M, Boroushak A. 2013. Polymorphism of SCD1 and DGAT1 gene in Isfahan Holstein cows. Int J Adv Biol Biomed Res. 1(7):783-788.

Ashwell MS, Ogg SL, Mather IH. 1996. The bovine butyrophilin gene maps to chromosome 23 . Anim Genet. 27(3):171-173. doi:10.1111/j.13652052.1996.tb00945.x.

Badola S, Bhattacharya TK, Biswas TK, Shivakumar BM, Kumar P, Sharma A. 2004. A comparison on polymorphism of beta-lactoglobulin gene in Bos indicus, Bos taurus and IndicinexTaurine crossbred cattle. AsianAustralas J Anim Sci. 17(6):733-736. 
Bhattacharya T, Misra S, Sheikh FD, Dayal S, Vohra V, Kumar P, Sharma A. 2004. Variability of milk fat globule membrane protein gene between cattle and riverine buffalo. DNA Seq. 15(5-6):326-331. doi:10.1080/10425170400019334.

Bhattacharya T, Sheikh F, Sukla S, Kumar P, Sharma A. 2007. Differences of ovine butyrophilin gene (exon 8) from its bovine and bubaline counter part. Small Ruminant Res. 69(1-3):198-202. doi:10.1016/j.smallrumres.2005.12.006.

Cobanoglu O, Zaitoun I, Chang Y, Shook G, Khatib H. 2006. Effects of the signal transducer and activator of transcription 1 (STAT1) gene on milk production traits in Holstein dairy cattle. J Dairy Sci. 89(11):44334437. doi:10.3168/jds.S0022-0302(06)72491-2.

Falconer D, Mackay TFC. 1996. Introduction to quantitative genetics. $4^{\text {th }}$ edition. Essex (UK): Addison Wesley Longman Ltd.

Franke WW, Heid HW, Grund C, Winter S, Freudenstein C, Schmid E, Jarasch ED, Keenan TW. 1981. Antibodies to the major insoluble milk fat globule membraneassociated protein: specific location in apical regions of lactating epithelial cells. J Cell Biol. 89(3):485-494. doi:10.1083/jcb.89.3.485.

Freudenstein C, Keenan TW, Eigel WN, Sasaki M, Stadler J, Franke WW. 1979. Preparation and characterization of the inner coat material associated with fat globule membranes from bovine and human milk. Exp Cell Res. 118(2):277-294. doi:10.1016/00144827(79)90153-8.

Geldermann H. 1975. Investigations on inheritance of quantitative characters in animals by gene markers I. Methods. Theoret Appl Genetics 46(7):319-330. doi:10.1007/BF00281673.

Grisart B, Coppieters W, Farnir F, Karim L, Ford C, Berzi P, Cambisano N, Mni M, Reid S, Simon P, Spelman R, Georges M, Snell R. 2002. Positional candidate cloning of a QTL in dairy cattle: identification of a missense mutation in the bovine DGAT1 gene with major effect on milk yield and composition. Genome Res. 12(2):222-231. doi:10.1101/gr.224202.

Husaini Y, Wilkins RJ, Davey HW. 1999. Identification of five point mutations, including an AluI RFLP, in the bovine butyrophilin gene. Anim Genet. 30(5):400401. doi:10.1046/j.1365-2052.1999.00526-23.x.

Ishii T, Aoki N, Noda A, Adachi T, Nakamura R, Matsuda T. 1995. Carboxy-terminal cytoplasmic domain of mouse butyrophilin specifically associates with a 150-kDa protein of mammary epithelial cells and milk fat globule membrane. Biochim Biophys Acta, Gen Subj. 1245(3):285-292. doi:10.1016/03044165(95)00102-6.

Jack LJ, Mather IH. 1990. Cloning and analysis of cDNA encoding bovine butyrophilin, an apical glycoprotein expressed in mammary tissue and secreted in associa- tion with the milk-fat globule membrane during lactation. J Biol Chem. 265(24):14481-14486.

Komisarek J, Dorynek Z. 2003. Polymorphism of BTN and GHR genes and its impact on bulls' breeding value for milk production traits. J Anim Feed Sci. 12(4):681-688. doi:10.22358/jafs/67762/2003.

Kumar M, Ratwan P, Vohra V. 2016a. Genetic variability and significance of STAT gene in dairy animals. Res Rev: J Dairy Sci Technol. 5:2319-3409.

Kumar M, Vohra V, Ratwan P, Chakravarty AK. 2016b. SNP identification in thioesterase domain of fatty acid synthase gene in Murrah buffaloes. J Anim Plant Sci. 26(6):1828-1832.

Kumar M, Vohra V, Ratwan P, Chopra A, Chakaravarty AK. 2017. Influence of FASN gene polymorphism on milk production and its composition traits in Murrah buffaloes. Indian J Anim Res. 51(4):640-643. doi:10.18805/ijar.7077.

Kumar M, Vohra V, Ratwan P, K Chakravarty A. 2015. Exploring polymorphism in 3' UTR region of STAT1 gene in different buffalo breeds. Indian J Dairy Sci. 68:473-76.

Mao Y, Zhong G, yc Z, Pen X, Yang Z, Wang Y, Jiang M. 2004. Genetic polymorphism of milk protein and their relationships with milking traits in Chinese yak. Asian-Australas J Anim Sci. 17(11):1479-483. doi:10.5713/ajas.2004.1479.

Mather IH, Jack LJ. 1993. A review of the molecular and cellular biology of butyrophilin, the major protein of bovine milk fat globule membrane. J Dairy Sci. 76(12):3832-3850. doi:10.3168/jds.s00220302(93)77726-7.

Muszyńska M, Szatkowska I, Grzesiak W, Dybus A, Zaborski D. 2010. Two single nucleotide polymorphisms within bovine butyrophilin gene (BTN/HaeIII and BTN/SchI) and their association with milk performance traits in Jersey cattle. Arch Anim Breed. 53(5):501-509. doi:10.5194/aab-53-501-2010.

Ogg SL, Weldon AK, Dobbie L, Smith AJH, Mather IH. 2004. Expression of butyrophilin (Btn1a1) in lactating mammary gland is essential for the regulated secretion of milk-lipid droplets. Proc Natl Acad Sci USA 101(27):10084-10089. doi:10.1073/pnas.0402930101.

Sadr AS, Nasiri MB, Alami-Saeid K, Fayazi J, Roshanfekr H, Mohammadi M. 2008. DNA polymorphism of butyrophilin gene by PCR-RFLP technique. Afr J Biotechnol. 7(14):2527-2529.

Sambrook J, Russell DW. 2001. Molecular cloning: a laboratory manual. $3^{\text {rd }}$ edition. volume 1 . New York: Cold Spring Harbor Laboratory Press.

Soyeurt H, Gillon A, Vanderick S, Mayeres P, Bertozzi C, Gengler N. 2007. Estimation of heritability and genetic correlations for the major fatty acids in bovine milk. J Dairy Sci. 90(9):4435-4442. 
doi:10.3168/jds.2007-0054.

SPSS Inc. 2001. SPSS for Windows.

Stoop W, van Arendonk J, Heck J, van Valenberg H, Bovenhuis H. 2008. Genetic parameters for major milk fatty acids and milk production traits of dutch Holstein-Friesians. J Dairy Sci. 91(1):385-394. doi:10.3168/jds.2007-0181.

Taylor C, Everest M, Smith C. 1996a. Restriction fragment length polymorphism in amplification products of the bovine butyrophilin gene: assignment of bovine butyronhilin to bovine chromosome 23 . Anim Genet. 27(3):183-185. doi:10.1111/j.13652052.1996.tb00948.x.

Taylor MR, Peterson JA, Ceriani RL, Couto JR. 1996b. Cloning and sequence analysis of human butyrophilin reveals a potential receptor function. Biochim Biophys Acta, Gene Struct Expression 1306(1):1-4. doi:10.1016/0167-4781(19)60000-X.

Vohra V, Chakravarty AK. 2011. Sustainable breeding in cattle \& buffalo. $1^{\text {st }}$ edition. New Delhi: Satish Serial Publishing House.

Vohra V, Kumar M, Chopra A, Niranjan SK, Mishra AK, Kataria RS. 2015. Polymorphism in exon-40 of FASN gene in lesser known buffalo breeds of India. J Anim Res. 5(2):325-328. doi:10.5958/2277940x.2015.00056.x.

Wooding FBP, Kemp P. 1975. High-melting-point triglycerides and the milk-fat globule membrane. J Dairy Res. 42(3):419-426. doi:10.1017/S0022029900015454.

Zegeye A, Ashwell M, Ogg S, Rexroad C, Mather IH. 1999. RFLP markers in the bovine butyrophilin gene. Anim Genet. 30(5):385-386. doi:10.1046/j.13652052.1999.00526-4.x. 